\title{
SPECIAL SECTION
}

\section{Introduction}

\section{Experiences of Time in the Ibero-American World, Eighteenth and Nineteenth Centuries}

\author{
JAVIER FERNÁNDEZ-SEBASTIÁN \\ University of the Basque Country, Bilbao, Spain
}

FABIO WASSERMAN

Instituto Ravignani, University of Buenos Aires, Conicet, Argentina

\begin{abstract}
In this introductory article, the authors argue that major changes in the way we conceive of time and temporality that are taking place today justify the increase of studies, both theoretical and empirical, on shifts in cultural constructions of time. In this context, the authors present four articles written by members of the network Iberconceptos, where a number of time experiences in the Ibero-American world (Latin America, Spain, and Portugal) during the eighteenth and nineteenth centuries are discussed from a conceptual perspective.
\end{abstract}

\section{KEYWORDS}

future, Latin America, nineteenth century, Spain, temporality, time

The enormous social, cultural, and technological transformations of recent decades have been accompanied by very significant changes in the ways we conceive of time and experience temporality. ${ }^{1}$ These changes have encouraged increasingly reflective attitudes, which have resulted in a growing body of historical scholarship with regard to historical modes of cultural constructions of time. Inspired by the great theories concerning time developed by certain

1 The authors of this introduction, as well as the other contributors to this special section, form part of Iberconceptos. Javier Fernández-Sebastián is the founder and general coordinator of this transnational network, and Fabio Wasserman coordinates the group specifically dedicated to historical research into the experiences of time in the Ibero-American world. The foundations of the project can be accessed at www.iberconceptos.net. This program is part of the work of the Group IT615-13 and the Research Project HAR201342779-P, financed by the Basque Department of Education, Universities and Research, and by the Ministry of Economy, Government of Spain, respectively. 
early twentieth-century philosophers (Husserl, Bergson, Heidegger, and others) and also by the contributions of prominent sociologists such as George $\mathrm{H}$. Mead, Norbert Elias, Niklas Luhmann, and others, a number of social scientists, among them some historians, have in recent years been devoting more and more attention to the problematique of temporality, both from theoretical-methodological perspectives and in terms of case studies. In the available bibliography on these issues we can find valuable essays and reflections concerning recent transformations in the temporal structures of our societies and in the experience of temporality, which sometimes involve profound changes in the relationship between the three classic dimensions of time. ${ }^{2}$ There are also more empirical studies, focused above all on the modern period, that analyze the diverse forms of experiencing, representing, segmenting, and conceptualizing the passage of time, including some works that have sought to narrate the progressive historical crystallization of those great abstractions that go by the names of "the past," "the present," and "the future."

One of the advantages of studies of this nature is their capacity to encourage intellectually more modest and reflexive attitudes. The ironic awareness of the historicity and contingency of our own conception of time opens up to us the possibility of conceiving of frameworks of temporality different from the chronotope in which we are installed and that we assume as part of common sense. This radical awareness of historicity thus opens the door to a semantic of historical temporalities, in plural, that would abandon the chronocentrism of an arrogant modernity that very often has regarded itself as the pinnacle of all time.

2. François Hartog, Régimes d'historicité: Présentisme et expériences du temps (Paris: Seuil, 2003); Hartmut Rosa, Social Acceleration: A New Theory of Modernity (New York: Columbia University Press, 2013).

3. Reinhart Koselleck, The Practice of Conceptual History: Timing History, Spacing Concepts (Stanford: Stanford University Press, 2002); Reinhart Koselleck, Futures Past: On the Semantics of Historical Times (New York: Columbia University Press, 2004); Reinhart Koselleck, Estratos do Tempo: Estudos sobre História (Rio de Janeiro: Contraponto/Editora PUC-Río, 2014); Christian Delacroix, François Dosse, and Patrick García, eds., Historicidades (Buenos Aires: Waldhuter, 2010); Lucian Hölscher, Die Entdeckung der Zukunft (Frankfurt am Main: Fischer Taschenbuch Verlag, 1999); Zachary Sayre Schiffman, The Birth of the Past (Baltimore: Johns Hopkins University Press, 2011); Fernando Nicolazzi, Helena Miranda Mollo, and Valdei Lopes de Araujo, eds., Aprender com a história? O pasado e o futuro de uma questão (Rio de Janeiro: FGV, 2011); Javier Fernández-Sebastián, ed., Political Concepts and Time: New Approaches to Conceptual History (Santander: McGraw Hill/Cantabria University Press, 2011); Myriam Revault d'Allonnes, La Crise sans fin: Essai sur l'expérience moderne du temps (Paris: Seuil, 2012); María Inés Mudrovcic and Nora Rabotnikof, eds., En busca del pasado perdido: Temporalidad, historia y memoria (Mexico City: Siglo XXI, 2013); Chris Lorenz and Berber Bevernage, eds., Breaking Up Time: Negotiating the Borders between Present, Past and Future (Göttingen: Vandenhoeck \& Ruprecht, 2013). 
Conceptual history, meanwhile, under the powerful influence of the œuvre of Reinhart Koselleck, has insisted upon the need for historians propaedeutically to question themselves vis-à-vis the historicity and internal temporality of the concepts they deal with (be these concepts forged by historians or notions used by agents of the past). This is an even more necessary historical scrutiny given that the constitution of the very history of concepts (Begriffsgeschichte) as an academic discipline might be considered to be one of the outcomes of the processes of temporalization and historization of the modern world. ${ }^{4}$

The four articles that make up this special section in this issue, written by members of one of the six teams in the Iberconceptos network, form part of a line of historiographical research halfway between conceptual history and studies of temporality. The group's objective is to analyze from a conceptual perspective the experiences of time in the Ibero-American world during the eighteenth and nineteenth centuries. ${ }^{5}$ In this sense, before briefly presenting the articles, let us first state some observations and caveats with regard to our specific approach.

The first observation is that our intention is not to carry out a theoretical investigation of time or temporality; what we actually seek to do is observeto a large extent by means of the careful semantic analysis of a sector of its vocabularies-how the actors in that crucial historical period conceptualized their experiences of time and how this intellectual operation of attribution of

4. Javier Fernández-Sebastián, "Historia, historiografía, historicidad: Conciencia histórica y cambio conceptual," in Europa del sur y América latina: Perspectivas historiográficas, Manuel Suárez Cortina, ed. (Madrid: Biblioteca Nueva, 2014), 35-64.

5. The group's activities include various workshops and two international conferences held in Bilbao and in São Paulo in November 2013 and April 2014, respectively. The first, in collaboration with a group led from Valencia University by Faustino Oncina, involved the participation of Ernst Müller, Giuseppe Duso, and Kirill Postoutenko, among others. The second led to the publication of a dossier titled "Experiencias de tiempo en los siglos XVIII y XIX iberoamericanos: Un abordaje desde la historia conceptual," Fabio Wasserman and João Paulo Garrido Pimenta, eds., Almanack 10 (2015): 233-366; this dossier includes the article "Experiences of Time and Conceptual Change in the Río de La Plata Revolutionary Process (1780-1840)" by Fabio Wasserman. In recent years other studies have also been published that, from different perspectives, totally or partially examine problems related to temporality in Ibero-America during the eighteenth and nineteenth centuries: Elías Palti, El tiempo de la política: El siglo XIX reconsiderado (Buenos Aires: Siglo XXI, 2007); Valdei Lopes de Araujo, A experiência do tempo: Conceitos e narrativas na formação nacional brasileira (1813-1845) (São Paulo: Hucitec, 2008); Víctor Goldgel, Cuando lo nuevo conquistó América: Prensa, moda y literatura en el siglo XIX (Buenos Aires: Siglo XXI, 2013); Javier Fernández Sebastián and Gonzalo Capellán, eds., Conceptos políticos, tiempo e historia: Nuevos enfoques en historia conceptual (Santander: McGraw Hill/Ediciones Universidad de Cantabria, 2013). 
(often controversial) meanings affected their discourse, their actions, and their expectations. The second is that our analysis centers on political and intellectual elites but, unlike the traditional history of ideas, strives to look beyond the great authors and major philosophical-political texts to encompass a corpus of sources-newspapers, pamphlets, manifestos, parliamentary debates, and so forth-that covers a range of social uses and conceptualizations far wider than the reduced textual canon normally adhered to by historians of political thought. In this case, the variety of sources should not be seen as a "historian's obsession"; it is rather a methodological necessity so that the reader might appreciate the diversity of discourses and ways of understanding (even opposed) regarding the same concepts. The third caveat is that while the period under consideration witnessed decisive transformations of the social, cultural, economic, scientific, and technological order, our approach favors political and intellectual changes as points of entry to explore experiences of time and its conceptualization by the actors of the day. In this respect, as can be observed in the articles, not only was there a temporalization of political concepts, but also a politicization of time, which had itself become a field of dispute. The fourth and final observation is that, beyond these general guidelines and some shared readings, the members of the Iberconceptos team that work on temporality and historicity - and therefore the authors of the articles that followhave constructed our object of study without following a unified theoretical pattern. We have neither begun with a definition a priori of historical time, nor have we restricted ourselves to any methodological orthodoxy. Thus, while some articles examine an author's work, a brief period, and/or a limited space, in others we propose a much more extensive investigation, whether to consider a diversity of authors and texts, or to cover a broader area or period.

In the first article, Maria Elisa Noronha de Sá and Marcelo Gantus Jasmin provide an analysis of the Portuguese-American world during the early decades of the nineteenth century, invoking the notion of chronotope coined by $\mathrm{M}$. Bakhtin and revived by H. U. Gumbrecht. In their article they analyze a series of texts by politician, scientist, and writer José Bonifácio de Andrada e Silva (1763-1838), who, after years promoting the regeneration of the LusoAmerican Empire under the influence of the Western Enlightenment, played a decisive role in the process of independence and constitution of Brazil as a nation in the 1820s. The work clearly shows that José Bonifácio successively employs the "same" concept of political regeneration in two opposite senses, applying it first to the Portuguese Empire and later to the brand-new Brazilian nation. In the next article, Ana Isabel González Manso concentrates on the historiography of peninsular Spain to examine how the changes in the conception of temporality influenced the way in which nineteenth-century Spanish writers rewrote the history of their nation, focusing her analysis on those who valued these transformations positively. Next, Francisco A. Ortega 
directs his attention toward what he calls "precarious time," referring to that of Spanish America during the first half of the nineteenth century and, more specifically, the New Granadan area (now Colombia). To this end he analyzes certain aspects of the work of the conservative politician and intellectual José Eusebio Caro (1817-1853), whose writings relate with considerable sensibility the changes in the experiences of time that affected his contemporaries in that period of transition, which, following the collapse of the monarchy, led to the construction of the new republican regime. The special section closes with an article in which Javier Fernández-Sebastián offers a synthesis of the perceptions and reflections on temporality voiced by a sector of Hispanic elites on both sides of the Atlantic between the late eighteenth and the mid-nineteenth centuries. Throughout this account his main aim is to observe the emergence of the new ways of apprehending and understanding the future. He draws attention to three key moments: the intellectual rupture promoted by the Enlightenment that attributed greater value to new experiences rather than habitual and established ones; the revolutionary and pro-independence processes that advocated a radical futurization of politics; and the constitution of the concept of future itself, understood as a new imaginary space about which there was increasing speculation from the 1830s onward.

These works, which take different objects and use different approaches and scales of analysis, represent but a sample of the possibilities offered by an investigation of the ways of experiencing and conceptualizing temporality in the eighteenth and nineteenth centuries in the Iberian and Ibero-American worlds. We trust that, as well as advancing knowledge of the region and this cultural field, they will also permit the establishment of a fruitful dialogue with those who analyze similar problems related to historicity and temporality in other areas and periods. 